Original Research Article

\title{
Seasonal status of density of phytoplankton in Asiganga River of Uttarkashi (Uttarakhand)
}

Bantwan, Babita

Department of Zoology Govt. P.G. College Nagnath Pokhari, Chamoli, Uttarakhand, India

Corresponding Author: babitabantwan85@gmail.com

\author{
A R T I C L E I N F O \\ Received: 21 January 2018 | Accepted: 22 April 2018 | Published Online: 15 August 2018 \\ DOI: $10.31786 / 09756272.18 .9 .1 .109$ \\ EOI: 10.11208/essence.18.9.1.109 \\ Article is an Open Access Publication. \\ This work is licensed under Attribution-Non Commercial 4.0 International \\ (https://creativecommons.org/licenses/by/4.0/) \\ CThe Authors (2018). Publishing Rights @ MANU_ICMANU \& ESSENCE-IJERC.
}

\begin{abstract}
A B S T R A C T
Phytoplankton play important role in biosynthesis of organic material and influence the river ecosystem, aquatic food chain and water characteristic. The biological productivity as ecological indicator to identify the ecological quality of River Asiganga. In River Asiganga the overall total density fluctuates from $0.0 \pm 0.00$ Unit 1-1 (April) to $673.5 \pm 303.35$ Unit 1-1 (March). During study period the total of phytoplanktons (29 genera) were noticed during different seasons. Present study concluded that seasonal differences of planktons density will help in further planning of water management and their use for beneficial purpose like agricultural, drinking for mankind.
\end{abstract}

\section{K E Y W O R D S}

Phytoplankton | Plankton density | Seasonal variation | River Asiganga

\section{I T A T I O N}

Bantwan, Babita (2018): Seasonal status of density of phytoplankton in Asiganga River of Uttarkashi (Uttarakhand), India. ESSENCE Int. J. Env. Rehab. Conserv. IX (1): 61—66. 


\section{Introduction}

Phytoplankton as primary producer plays a pivotal role in fixation of solar energy and makes it available to the higher level. It also forms an important link between the abiotic and biotic in the aquatic ecosystem. Phytoplankton consists of diverse assemblage of algae in the streams having different physiological requirements in response to physical and chemical parameters such as light, temperature and nutrients. Seasonal variation in planktons density are result of a complex interplay of physical, chemical and biological process, which indicate the diversity in ecological niches (Bansal et al., 1989). Planktons diversity is controlled by seasonal chages as well as by the rate at which plant nutrients are supplied. Nitrogen, phosphorus and silica are three main nutrients needed for the phytoplanktons to grow at different times and in different ratio (Pilkaityte, 2003).

\section{Materials and methods}

River Asiganga is located in district Uttarkashi which is formed by the confluence of Kaldi Gad and Gajoli Gad at Sangamchatti (1540 msl). River Asiganga is the one of the major tributary of River Bhagirathi which merges with River Bhagirathi at Gangori (1436 msl). In the present investigation focus were made on the study of phytoplankton of River Asiganga of Garhwal Himalaya.

Two sampling sites viz., S1 (Sangamchatti) and S2 (Gangori) were selected and sampling was done at both the sites at monthly interval from November 2008 to October 2009. Phytoplankton samples were collected by filtering 100 litre of water through phytoplankton net of $20 \mu \mathrm{m}$ size and preserved using 4\% formalin. Phytoplankton was identified up to the lowest recognizable taxonomic unit mostly genus following keys by Needham and Needham (1962); Ward and Whipple (1959); Sarode and Kamat (1984). Phytoplankton was enumerated using SedgwickRafter Cell Counter and number of phytoplankton ml-1 of water was calculated according to Welch (1952).

\section{Results}

A total of 29 genera of phytoplankton were collected and identified from the River Asiganga during the study period from November 2008 to October 2009. The Phytoplankton diversity inhabiting river Asiganga comprised of 29 genera out of which chlorophyceae constituted 15 genera, bacillariophyceae with 12 genera and myxophyceae had just 2 genera. The diversity of bacillariophyceae biomass was dominating the river Asiganga.

The chlorophyceae had the maximum contribution $51.70 \%$ (August) at S2 to minimum $4.40 \%$ (December) at S1. The bacillariophycae contributes maximum of $95.05 \%$ (December) at $\mathrm{S} 1$ to minimum $48.25 \%$ (August) at S2. At site S1 the myxophyceae contributes varied from $0.00 \%$ (November, March, April, May, June, August, October) to $9.60 \%$ (February) (Table 1).

Monthly variation in the abundance of important phytoplankton of river Asiganga has been presented in table 2. Quantitative fluctuation in the phytoplankton density of River Asiganga during the study period has been depicted in figure 1. In River Asiganga the overall total density fluctuates from $0.0 \pm 0.00$ Unit $1-1$ (April) to $673.5 \pm 303.35$ Unit $1^{-1}$ (March). The green algae (chlorophyceae) had the largest contribution followed by diatoms (bacillariophyceae), than followed by myxophyceae.

The total density of chlorophyceae was minimum $25.0 \pm 12.73$ (December) to maximum $157.0 \pm$ 111.72 (March). Seasonal density of chlorophyceae ranged from minimum $28.0 \pm 4.32$ Unit $1-1$ (winter) at site S2 to maximum $108.0 \pm 20.17$ Unit 1-1 (summer) at site S1.The total density of bacillariophyceae ranged from $103.0 \pm 24.04$ Unit $1-1$ (September) to $673.5 \pm 303.35$ Unit 1-1 (March). Seasonal density of bacillariophyceae ranged from minimum $2.89 \pm 123.60$ Unit $1-1$ (winter) at site $\mathrm{S} 1$ to maximum $345.0 \pm 303.82$ Unit 1-1 (summer) at site S1.The total density of myxophyceae varied from $0.0 \pm 0.00$ Unit 1-1 (April) to $15.0 \pm 12.73$ (February). Seasonal density myxophyceae ranged from minimum $4.0 \pm$ 2.00 Unit 1-1 (monsoon) at site S1 to maximum 
ESSENCE_-IJERC | Babita, Bantwan et al. (2018) | IX (1): 61-66

$15.0 \pm 12.73$ Unit 1-1 (summer) at site S2. (Table 3 $\&$ Figure 2).

\section{Discussion}

Phytoplanktons are microscopic single celled aquatic plants forming the prime component in the food chain of an aquatic ecosystem. Some

phytoplankton species are also often used as good indicators of water quality including pollution (Rajashree, 1993). Phytoplankton can be used as bio-indicators since they reflect even the slight changes taking place in their immediate environment by changing their species composition, biomass, community structure, chlorophyll pigment content and productivity moreover and marine ecosystem is largely determined by their phytoplankton population (Mohamed et al., 2009). Phytoplankton abundance and composition in aquatic ecosystems are regulated by abiotic factors such as, nutrients related to physico-chemical variability and biotic, trophic interactions (Sin et al., 1999; Lewis, 2000; Matta et al., 2018).

A total of 29 phytoplankton genera was identified during the study period, the over all total density fluctuates from $0.0 \pm 0.00$ Unit 1-1 (April) to 673.5 \pm 303.35 Unit 1-1 (March).

A total of 3 groups of Phytoplankton were identified such as chlorophyceae, bacillariophyceae and myxophyceae. Bacillariophyceae was the dominant group at both the sites followed by chlorophyceae and myxophyceae. Changes in the phytoplankton populations were clearly evident more in relation to physical than to chemical conditions of the water. Changes in water-level, nutrients contents and temperature affected the growth of the phytoplankton. Maximum concentration of bicarbonate and $\mathrm{pH}$ increased the growth of growth of diatoms and blue-green algae. Higher concentrations of phosphates and silicates with nitrates and nitrites contents were responsible for high phytoplankton yields in summer and winter seasons (Matta et al., 2015). Bhatnagar et al. (2013) have also reported a similar trend of phytoplankton dominance in River Yamuna.

It has noticed that density of phytoplankton was maximum in summer, minimum in monsoon season and intermediate in winter season. Data of av- erage value of seasonal density of recorded phytoplankton in the Asiganga River at study area has given in table 3. Present findings are in accordance with the finding of other workers. Singh (1990) reported that plankton population showed bimodel, pattern of fluctuation with one peak in pre winter and other in summer. Shinde et al., (2012); Kumar and Khare (2015); Hassan et al. (2010) observed minimum density of phytoplankton during monsoon and maximum during in summer.

In the hill streams water temperature, flow and substrate composition may be considered as the major factor controlling the phytoplankton communities (Wetzel, 1983). Factors controlling phytoplankton growth includes light, temperature, water current, substrate, water chemistry and invertebrate grazing, all these factors have potential effects on periphytonic populations (Whitton, 1975; Hynes, 1971; Biggs, 1996). According to Hynes (1971) water movement, turbidity, temperature and

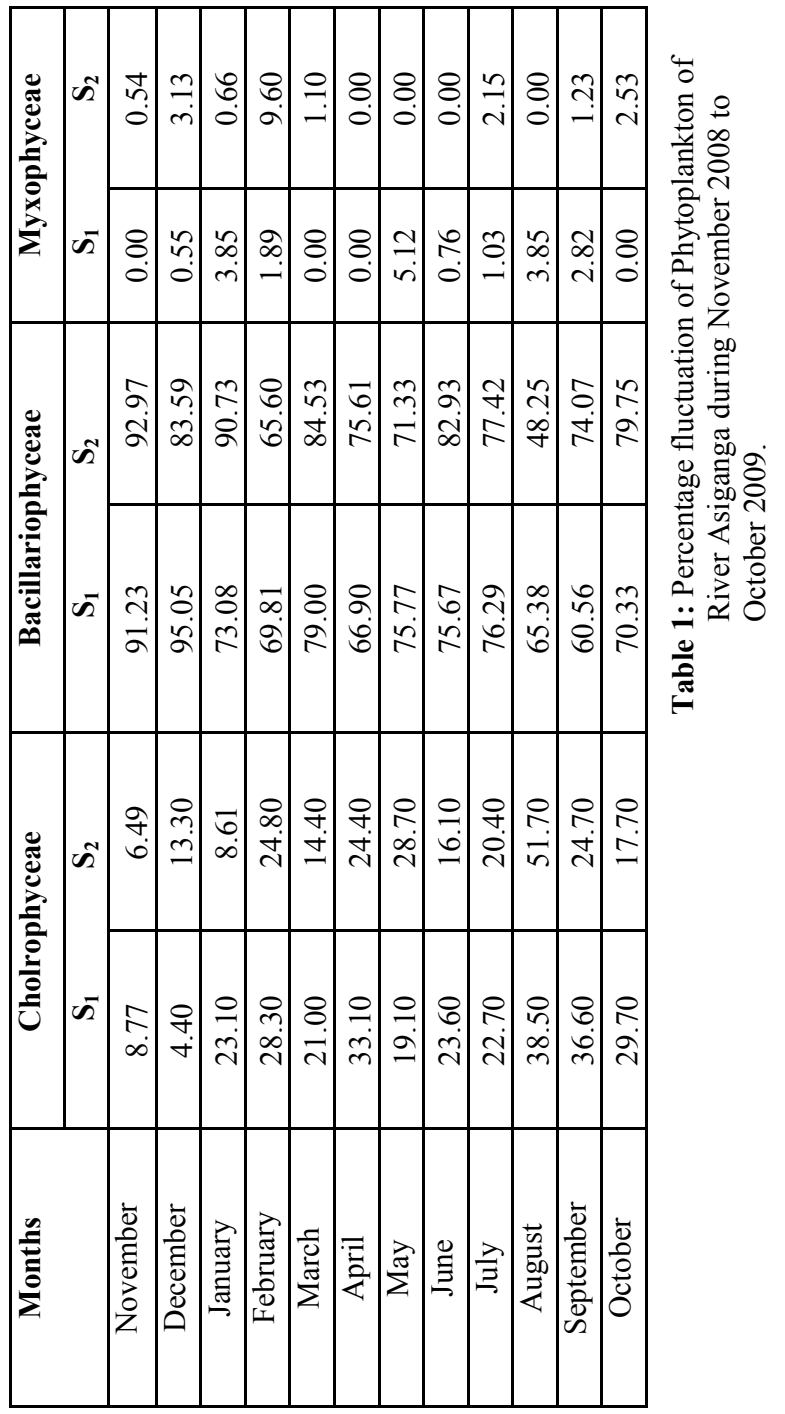


Turbidity has a negative impact on the growth of plankton in the river Chandrabhaga (Sharma et al., 2007). Similar observations have been recorded by Hynes (1971) in Volga River. Chandler (1937) and Cushing (1965) report that mechanical destruction of plankton occurs by the grinding action of water heavily laden with silt. Same reason may be of low phytoplankton density during the study period in monsoon season in river Asiganga.

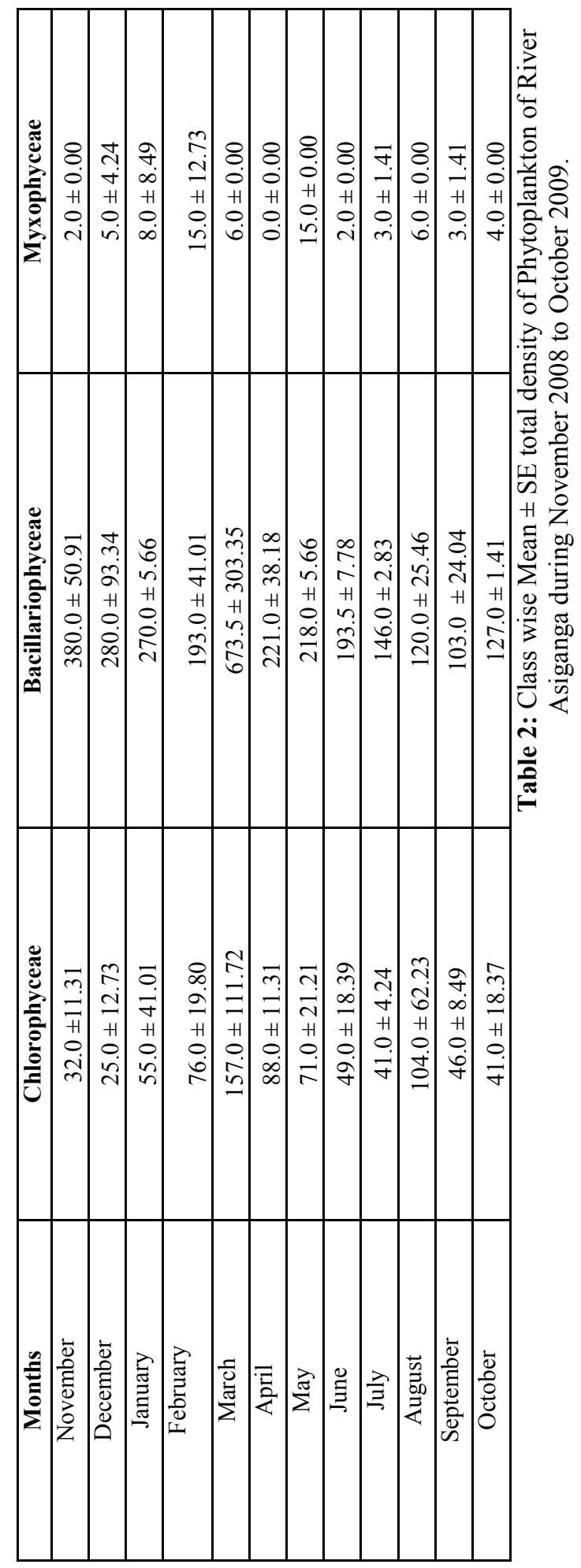

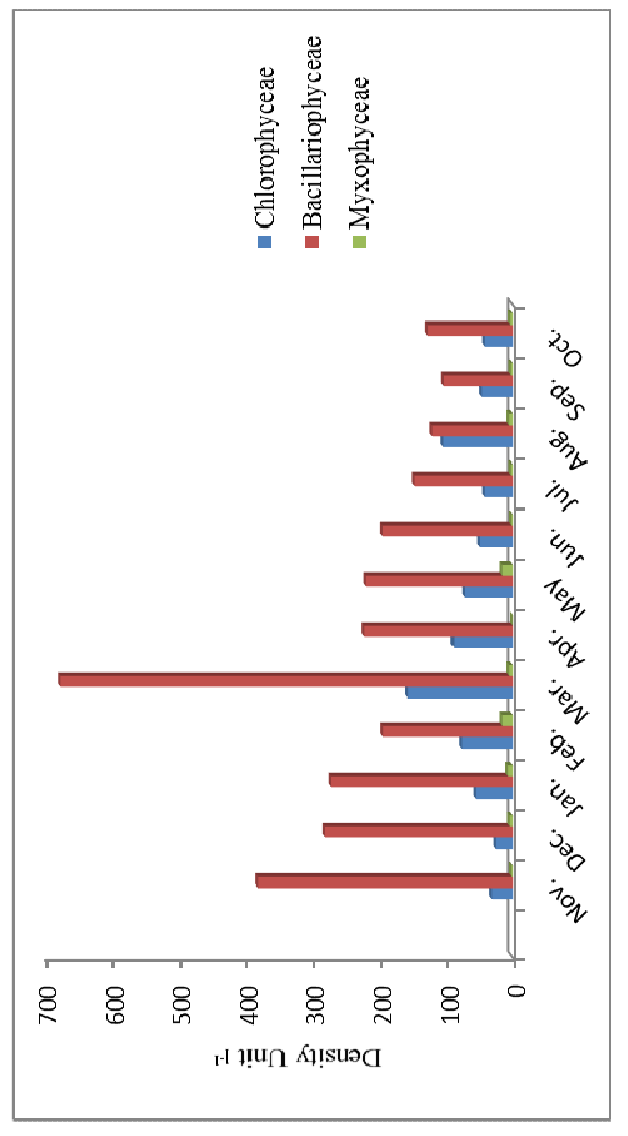
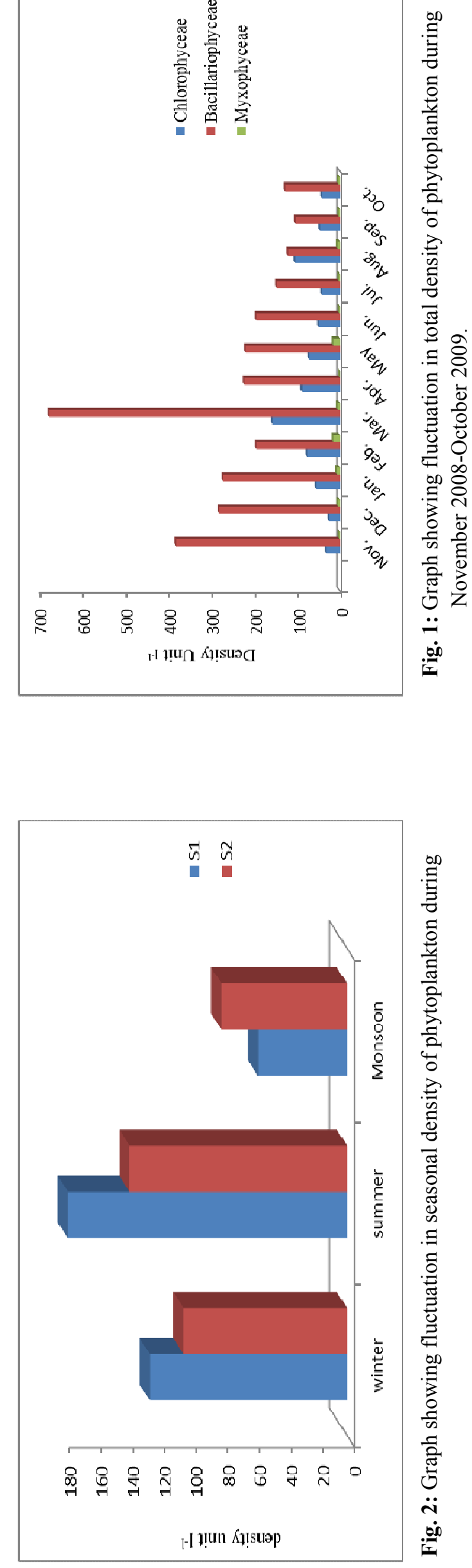


\section{References}

Bansal, N. R.; Naokarni, V. B. and Gourder, B. Y. M. (1989): Ecology of zooplankton of supra reservoir of Kalirner during the filling phase, Karnataka. J. Fresh water Biol. 1(1):15-23.

Bhatnagar, A.; Chopra, G. and Malhotra, P. (2013): Assessment of water quality of river Yamuna in Yamunanagar, India with reference to planktons and macrozoobenthos. Sch. J. Eng. Tech. 1(4): 204-213.

Biggs, B. J. F. (1996): Patterns in Benthic Algae of Streams: In: Algal Ecology Freshwater Benthic Ecosystems (Eds.) R.J Stevenson, M.L Bothwell and R.L. Lowe. Academic Press, New York.

Chandler, O. C. (1937): Fate of typical lake Plankton in streams. Ecol Monogr.7: 445-75.

Cushing, E. C. (1965): Plankton and water chemistry in the Montreal River lake stream, Sasketchewan. Ecology. 45: 306- 13.

Hassan, Fikrat M.; Taylor, W. D.; Mayson, M. S.; Al-Taee and Hassan, J. J. (2010): P h y t o plankton composition of Euphrates river in Al-Hindiya barrage and Kifil city region of Iraq. J. Environ. Biol. 31: 343-350.

Hynes, H. B. N. (1971): The Ecology of Running Waters. Liverpool University Press Liverpool. 1-555.

Kumar, M. and Khare, P. K. (2015): Diversity of plankton and their seasonal variation of density of the Yamuna river at Kalpi, District Jalaun (U.P.) India. J. Global Biosci. 4(7): 2720-2729.

Lewis, Jr. M. W. (2000): Basis of the protection and management of tropical lakes. Lakes and Reservoirs: Research and Management. 5: 35 -48 .

Matta, G. (2010): "Freshwater: Resources and Pollution" Environment Conservation Journal, 11 (3): 161-169

Matta, G. (2014): "A study on physico-chemical Characteristics to assess the pollution status of river Ganga in Uttarakhand." Journal of Chemical and Pharmaceutical Sciences. 7(3): 210-217.
Matta, G. (2015): Effect of water quality on phytoplankton ecology of Upper Ganga Canal, International Journal of Scientific \& Engineering Research, 6(2): 762-768.

Matta, G. and Kumar, A. (2015): Monitoring and Evaluation of River Ganga System in Himalayan Region with Reference to Limnological Aspects - World Applied Sciences Journal, 33 (2): 203-212.

Matta, Gagan; Kumar, Avinash; Dhingra, Gulshan K.; Singh, Prashant, Gjyli, Laura, Kumar, Amit (2018): Limnological assessment of anthropogenic activities of River Henwal. Journal of Chemical and Pharmaceutical Sciences. 11(1).

Matta, G.; Kumar, A.; Srivastava, S.; Singh, V. and Dhingra, G. K. (2015): Impact assessment on water quality of Ganga Canal System in Himalayan Region. International Journal of Scientific \& Engineering Research, 6 (5): $1524-1531$.

Matta, G.; Kumar, A.; Uniyal, D. P.; Singh, P.; Kumar, A.; Dhingra, G. K.; Kumar, A.; Naik, P. K. and Shrivastva, N. G. (2017): Temporal assessment using WQI of River Henwal, a Tributary of River Ganga in Himalayan Region. ESSENCE Int. J. for Env. Rehab. And Conser. 8(1): 187-204

Matta, G.; Panday, R. R. and Saini, K. K. (2015): Assessment of pollution on water quality and phytoplankton diversity in canal system of River Ganga. World J. Pharma. Res. 889908.

Matta, Gagan; Kumar, Avinash; Naik, Pradeep K., Tiwari, A. K. and Berndtsson, R. (2018): Ecological Analysis of Nutrient Dynamics and Phytoplankton Assemblage in the Ganga River System, Uttarakhand. Taiwan Water Conservancy. 66 (1): $1-12$.

Matta, G.; Srivastava, S.; Pandey, R. R. and Saini, K. K. (2015b): Assessment of physicochemical characteristics of Ganga Canal water quality in Uttarakhand. Environ Dev Sustain. DOI 10.1007/s10668-015-9735-X 
ESSENCE_-IJERC | Babita, Bantwan et al. (2018) | IX (1): 61-66

Matta, G. and Uniyal, D. P. (2017): Assessment of Species Diversity and Impact of Pollution on Limnological conditions of River Ganga. Int. J. Water, 11(2): 87-102.

Matta, G.; Laura, G.; Kumar, A. and Machel, J. (2018a): Hydrochemical characteristics and Rajashree, G. and Panigrahy, R. C. (1993): planktonic composition assessment of River Henwal in Himalayan Region of Uttarakhand using CPI, Simpson's and Shannon-Weaver Index. Journal of Chemical and Pharmaceutical Sciences. 11(1).

Matta, Gagan; Naik, Pradeep K.; Machell, John; Kumar, Amit; Gjyli, Laura; Tiwari, Ashwani Kumar and Kumar, Avinash (2018b): Comparative study on seasonal variation in hydrochemical parameters of Ganga river water using comprehensive pollution index (CPI) at Rishikesh, (Uttarakhand) India. Desalination and Water Treatment; 118 (June): 87-95; doi: 10.5004/dwt.2018.22487

Matta, Gagan; Kumar, Amit; Kumar, ; Naik, Pradeep K. and Avinash Kumar (2018d): Applicability of Heavy Metal Indexing on Ganga River System assessing heavy metals toxicity and ecological impact on river water quality. INAE Letters, An Official Journal of the Indian National Academy of Engineering.

Matta, Gagan; Kumar, Avinash; Tiwari, A. K; Naik, Pradeep K. and Berndtsson, R. (2018e): HPI appraisal of concentrations of heavy metals in Dynamic and static flow of Ganga River System. Environment, Development and Sustainability, Springer Nature. DOI 10.1007/s10668-018-01182-3

Mohamed, A. S.; Thirumaran, G.; Arumugam, R.; Kannan, R. R. and Anantharaman, P. (2009): Studies of phytoplankton diversity from Agnitheertham and Kothandaramar Koil Coastal Waters, Southeast Coast of India. Aristotle University of Thessaloniki, School of Biology, Laboratory of Ichthyology, GR-54124, Thessaloniki, Greece; Ul. Politechniczna, PL32020 Wieliczka, Poland. Biologia, Bratislava. J. Environ. Res. 59(2):119-124.

Needham, J. G. and Needham, P. R. (1962): A Guide to the study of freshwater biology,
Holdan Day Inc. San. Francisio.

Pilkaityte, R. (2003): Phytoplanktons seasonal sucession and abundance in the eutophic estuarine lagoons. Doctoral dissertation thesis, Klaipeda, 97.

Monthly variations of some hydrographic parameters in the Rushikulya estuary east coast of India. Mahasgar Bulletin National Institute Oceanogr, 26 (2):73-85.

Sarode, P. T. and Kamat, N. D. (1984): Freshwater Diatoms of Maharashtra. Saikripa Prakashan, Aurangabad.

Sharma, A., Sharma, R. C. and Anthwal, A. (2007): Monitoring phytoplankton diversity in the hill stream Chandrabhaga of Garhwal Himalaya. Life Science Journal. 4(1): 80-84.

Sin, Y., Wetzel, L. R. and Anderson, C. I. (1999): Spatial and temporal characteristics of nutrient and phytoplankton dynamics in the York River Estuary, Virginia: Analyses of longterm data. Estuaries. 22: 260-275.

Shinde, S. E., Pathan, T. S. and Sonawane, D. L. (2012): Seasonal variations and biodiversity of phytoplankton in Harsool-Savangiolam, Aurangabad, India. J. Envi. Bio. 33: 643-647. Singh, D. N. (1990): Diurnal vertical migration of plankton in Mcpherson lake Allahabad, Pro. Nat. Acad. Sci. India. 60(B)-II.

Ward, H. B. and Whipple, G. G. (1966): Freshwater Biology (Eds.) W.T. Edmondson, John. Willy \& Sons, Inc. New York.

Welch, P. S. (1952): Limnological Methods, XVIII Macgrow Hill Brok Co. Inc. New York.

Wetzel, R. G. (1983): Limnology, 2 nd edn. Saunders College Publishing Co., New York. 767.

Whitton, B. A. (1975): Algae. In: River Ecology. (ed.) B.A. Whitton. Blackwell Science Publication, Oxford. 81-105. 